Prepared in cooperation with the Camp Stanley Storage Activity Environmental Management Office and the Parsons Corporation

\title{
Three-Dimensional Model of the Hydrostratigraphy and Structure in and around the U.S. Army-Camp Stanley Storage Activity Area, Northern Bexar County, Texas
}

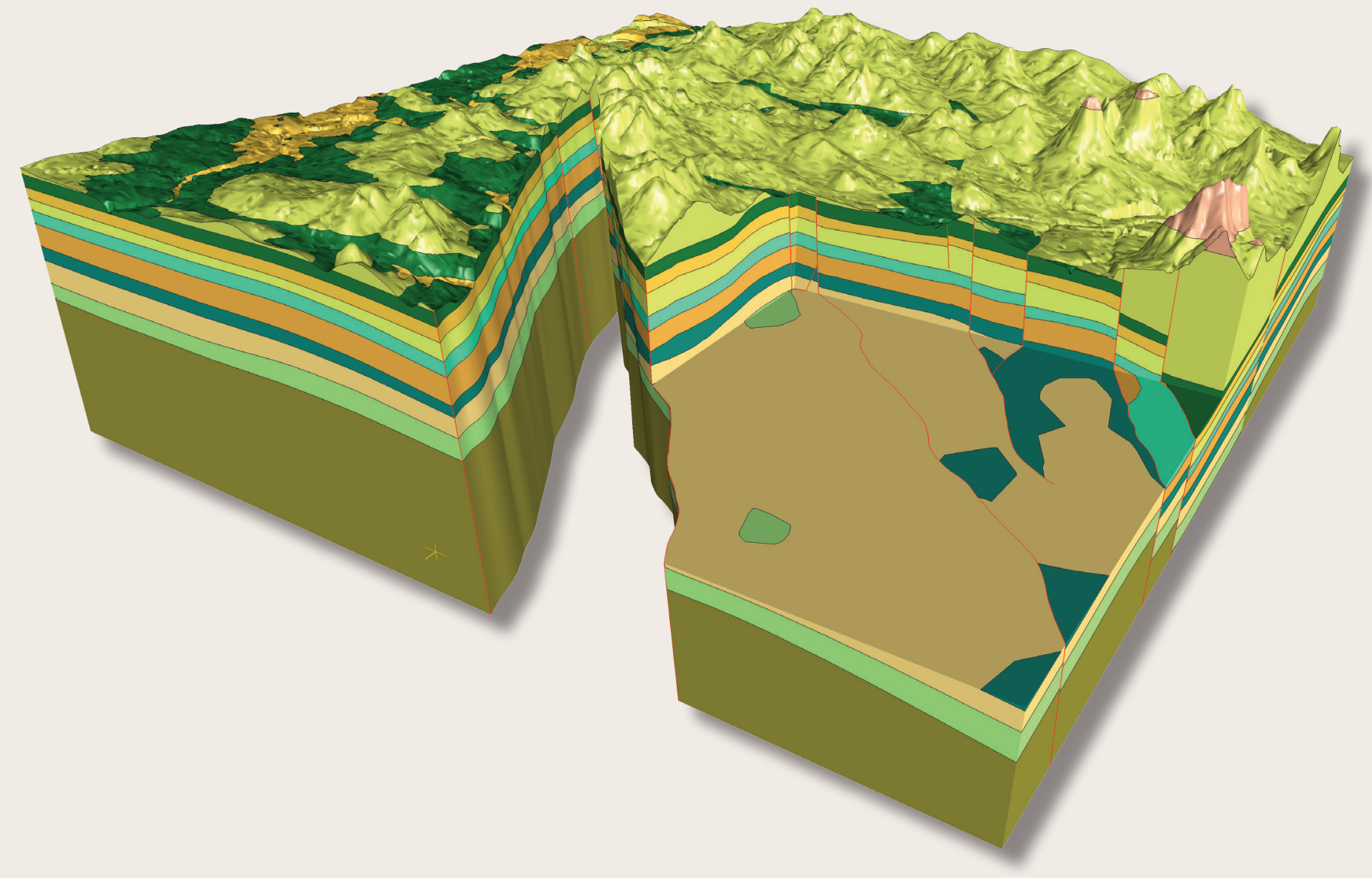

Scientific Investigations Report 2014-5074 



\section{Three-Dimensional Model of the Hydrostratigraphy and Structure in and around the U.S. Army-Camp Stanley Storage Activity Area, Northern Bexar County, Texas}

By Michael P. Pantea, Charles D. Blome, and Allan K. Clark

Prepared in cooperation with the Camp Stanley Storage Activity Environmental Management Office and the Parsons Corporation

Scientific Investigations Report 2014-5074 


\title{
U.S. Department of the Interior SALLY JEWELL, Secretary
}

\section{U.S. Geological Survey Suzette M. Kimball, Acting Director}

\author{
U.S. Geological Survey, Reston, Virginia: 2014
}

For more information on the USGS - the Federal source for science about the Earth, its natural and living resources, natural hazards, and the environment, visit http://www.usgs.gov or call 1-888-ASK-USGS.

For an overview of USGS information products, including maps, imagery, and publications, visit http://www.usgs.gov/pubprod

To order this and other USGS information products, visit http://store.usgs.gov

Any use of trade, firm, or product names is for descriptive purposes only and does not imply endorsement by the U.S. Government.

Although this information product, for the most part, is in the public domain, it also may contain copyrighted materials as noted in the text. Permission to reproduce copyrighted items must be secured from the copyright owner.

Suggested citation:

Pantea, M.P., Blome, C.D., and Clark, A.K., 2014, Three-dimensional model of the hydrostratigraphy and structure of the area in and around the U.S. Army-Camp Stanley Storage Activity Area, northern Bexar County, Texas: U.S. Geological Survey Scientific Investigations Report 2014-5074, 13 p., http://dx.doi.org/10.3133/sir20145074. 


\section{Contents}

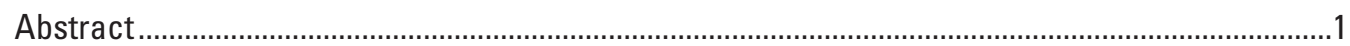

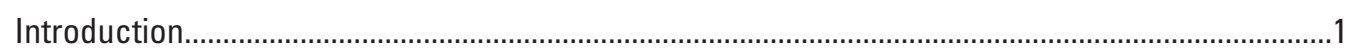

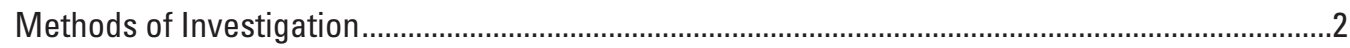

3-D Model Development and Data Management........................................................................

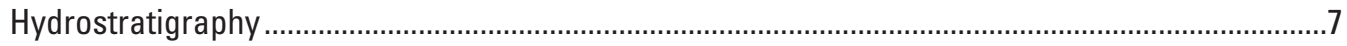

Modeled Edwards Aquifer Hydrostratigraphic Units (Edwards) .............................................8

Modeled Upper Trinity Aquifer Hydrostratigraphic Units (Upper_GlenRose) ...........................8

Modeled Middle Trinity Aquifer Hydrostratigraphic Units.........................................................

Following are both Hydrostratigraphic and Lithostratigraphic Units..............................10

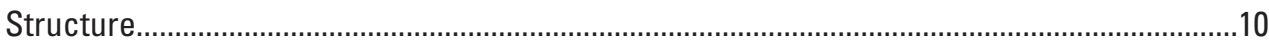

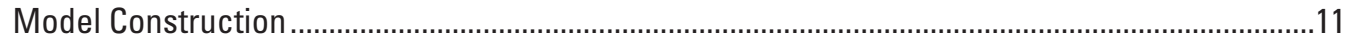

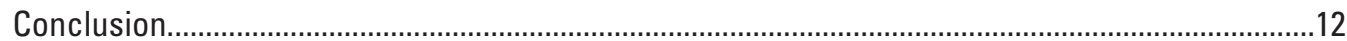

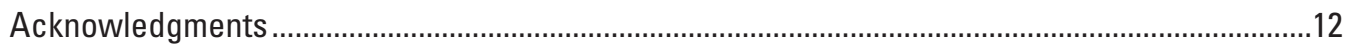

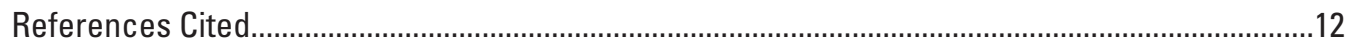

\section{Figures}

1. Index map showing location of model area, Camp Stanley Storage Activity Area, Bexar County, Texas, and 7.5 minute quadrangles covered ....................................2

2. Stratigraphic and hydrostratigraphic correlation chart of modeled units.........................

3. View of faulted top of Hammett hydrostratigraphic unit, cross section showing hydrostratigraphic units, and faults used in the model.........................................

4. Well locations, previously mapped faults, and mapped surface lithology within the U.S. Army-Camp Stanley Storage Activity Area (CSSA) model area ...........................5

5. Study area, orthophoto quadrangle image, original structure overlay, core type log drill-hole locations, and the Camp Stanley Storage Activity Area boundary...................6

6. Fourteen faults used in the construction of the three-dimensional model as related to the previously mapped faults ..........................................................................

7. Fourteen modeled faults, fault dip direction and the range of calculated displacements along the fault plane ...............................................................................

8. The 3-D model area, surface topology, surface and subsurface hydrostratigraphic units, and structure ...........................................................................................................

9. Horst and graben structures in northeast part of model area, view is from northeast looking southwest.

\section{Conversion Factors}

Inch/Pound to SI

\begin{tabular}{lcl}
\hline Multiply & By & To obtain \\
\hline & Length & \\
inch (in.) & 2.54 & centimeter $(\mathrm{cm})$ \\
inch (in.) & 25.4 & millimeter $(\mathrm{mm})$ \\
foot (ft) & 0.3048 & meter $(\mathrm{m})$ \\
mile (mi) & 1.609 & kilometer $(\mathrm{km})$ \\
\hline
\end{tabular}

Models $X$ and $Y$ coordinates are Universal Transverse Mercator (UTM), Ellipsoid, GRS 1980/NAD 83, zone 14 in meters, and Z is elevation in feet, mean sea level (MSL), North American Datum, 1983. 



\title{
Three-Dimensional Model of the Hydrostratigraphy and Structure of the Area in and around the U.S. Army-Camp Stanley Storage Activity Area, Northern Bexar County, Texas
}

\author{
By Michael P. Pantea, Charles D. Blome, and Allan K. Clark
}

\section{Abstract}

A three-dimensional model of the Camp Stanley Storage Activity area defines and illustrates the surface and subsurface hydrostratigraphic architecture of the military base and adjacent areas to the south and west using EarthVision software. The Camp Stanley model contains 11 hydrostratigraphic units in descending order: 1 model layer representing the Edwards aquifer; 1 model layer representing the upper Trinity aquifer; 6 model layers representing the informal hydrostratigraphic units that make up the upper part of the middle Trinity aquifer; and 3 model layers representing each, the Bexar, Cow Creek, and the top of the Hammett of the lower part of the middle Trinity aquifer.

The Camp Stanley three-dimensional model includes 14 fault structures that generally trend northeast/southwest. The top of Hammett hydrostratigraphic unit was used to propagate and validate all fault structures and to confirm most of the drill-hole data. Differences between modeled and previously mapped surface geology reflect interpretation of fault relations at depth, fault relations to hydrostratigraphic contacts, and surface digital elevation model simplification to fit the scale of the model. In addition, changes based on recently obtained drill-hole data and field reconnaissance done during the construction of the model.

The three-dimensional modeling process revealed previously undetected horst and graben structures in the northeastern and southern parts of the study area. This is atypical, as most faults in the area are en echelon that step down southeasterly to the Gulf Coast. The graben structures may increase the potential for controlling or altering local groundwater flow.

\section{Introduction}

Areas just north of San Antonio, Texas (Tex.), to Oklahoma are home to nearly 10 million people whose sole or partial source of water is supplied by the Trinity aquifer (fig. 1). The Trinity aquifer is the only major aquifer in central Texas and consists of three hydrologic zones (upper, middle, and lower; Ashworth, 1983). The upper member of the Glen Rose Limestone forms the upper Trinity aquifer (Ashworth, 1983; fig. 2). The upper Trinity aquifer contains little water and often has high total dissolved solids because of evaporite dissolution (Camp Stanley Storage Activity, 2013). The lower member of the Glen Rose Limestone, the Bexar Shale, and Cow Creek Limestone Members of the Pearsall Formation form the middle Trinity aquifer (fig. 2). The Hammett Shale Member of the Pearsall Formation forms a confining unit between the middle and lower Trinity aquifers (Barker and Ardis, 1996). The lower Trinity aquifer is not included in the model.

The U.S. Army-Camp Stanley Storage Activity (CSSA) partnered with the U.S. Geological Survey (USGS) to develop a subsurface three-dimensional (3-D) model of the framework geology within the CSSA and surrounding area. The purpose of the study was to identify the hydrostratigraphic information using data collected from drill holes within the camp and in the surrounding communities. For more information, go to the CSSA website, at http://www.stanley.army.mill.

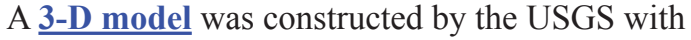
support from the CSSA areas Environmental Office and the USGS National Cooperative Geologic Mapping Program (NCGMP), using EarthVision (EV) geologic modeling software. The model encompasses areas within the Camp Bullis and Van Raub 1:24,000 quadrangles (fig. 1) and quantatively depicts the hydrostratigraphy and structure of the area (Blome and Smith, 2012, figs. 2 and 3). This interactive model integrates geophysical data and surface geologic maps (fig. 4) to interpret and build a 3-D rendering of the hydrostratigraphy and structure both on the surface and in the subsurface.

This 3-D model was developed to better understand the subsurface geology, and as a tool to help resource managers understand the various structural controls on groundwater flow. 


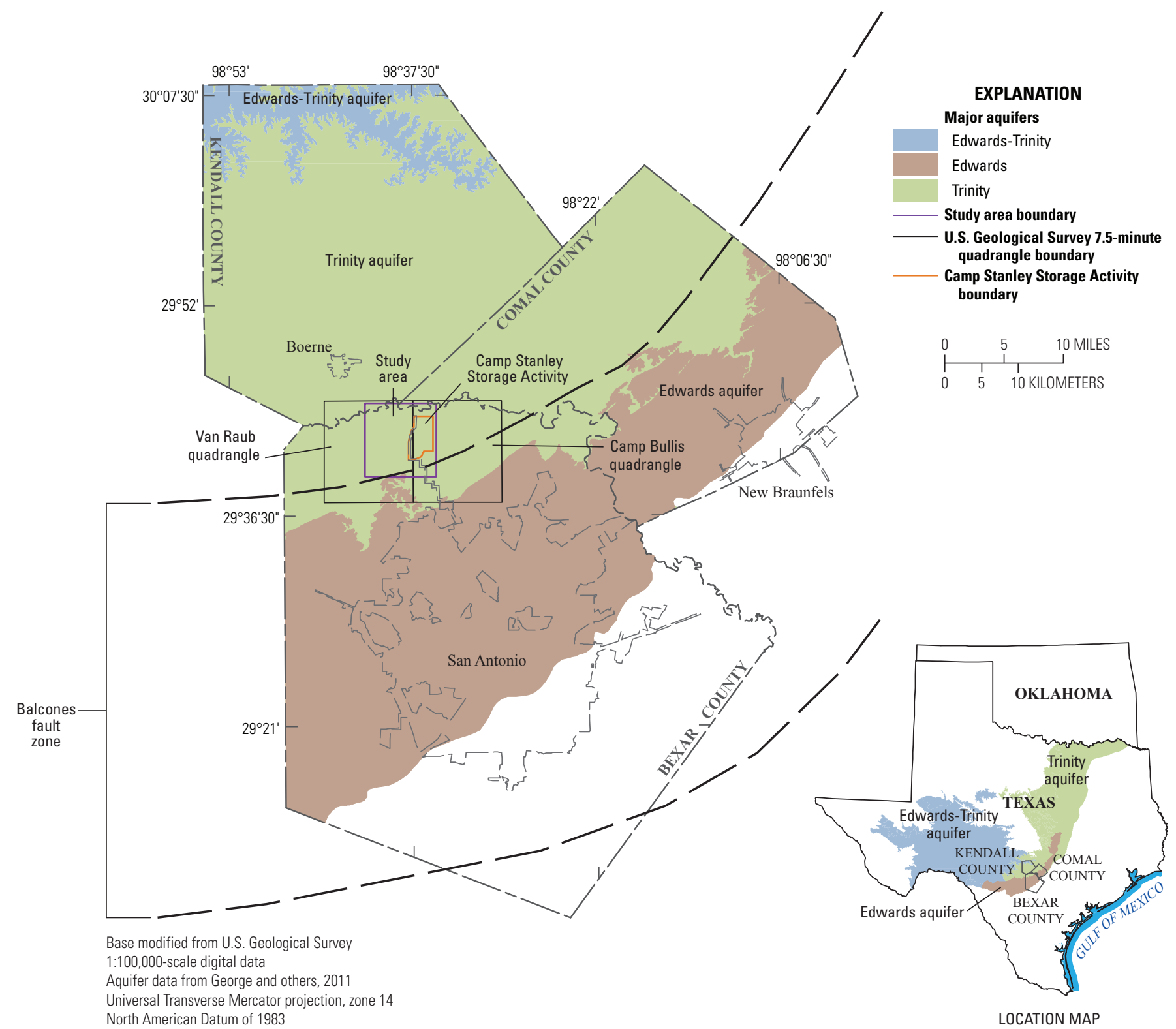

Figure 1. Index map showing location of model area, Camp Stanley Storage Activity Area, Bexar County, Texas, and 7.5 minute quadrangles covered.

\section{Methods of Investigation}

The geology and hydrostratigraphy of the surface and subsurface were obtained from previously published reports (Clark, 2003, 2004; Clark and others, 2009; Blome and Clark, 2014). Subsurface geophysical logs were obtained from contractors working for CSSA. These logs were received in Log ASCII Standard format (LAS) and imported into WellCAD, a drillhole analysis software package, and reformatted to a common scale. Paper geophysical logs were used to correlate between wells and to annotate geologic and hydrostratigraphic contacts. All correlated drill-hole data were compiled into a spreadsheet for use in the 3-D model. The modeling process allowed cross validation of the data. Any anomalies or discrepancies forced a verification of the surface geology, faults, and drill-hole data. Discrepancies confirmed during these investigations were corrected in the model and appropriate databases.

Two geologic cores, MW5-LGR and MW9-CC (fig. 5), were obtained from CSSA and sent to the USGS Core Research Center for storage, slabbing, and preparation for analysis. The geophysical log for MW9-CC was used as the typical log for the 3-D model area (Blome and Clark, 2014). Lithologic character and type of porosity for hydrostratigraphic units in the log MW9-CC were described by Blome and Clark (2014) following the porosity classification of Choquette and Pray (1970) and the classification system of Dunham (1962) for lithologic descriptions. Core plugs 


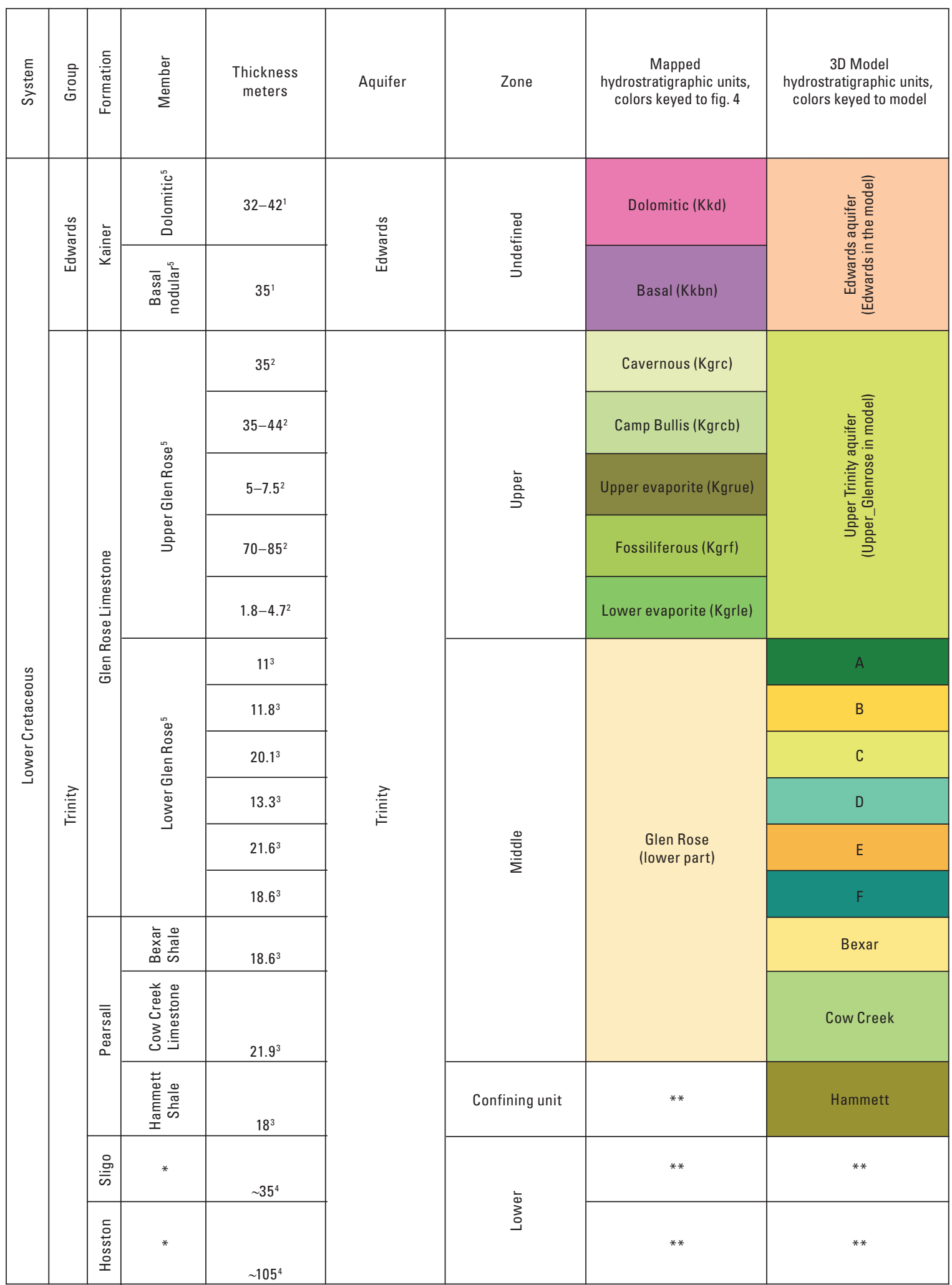

'Stein and Ozuna (1995)

${ }^{2}$ Clark and others (2009).

${ }^{3}$ Geophysical logs used in this study.

${ }^{4}$ Barker and Ardis (1996).

Informal members.

*Not subdivided into members.

**Not mapped or subdivided hydrostratigraphically.

Figure 2. Stratigraphic and hydrostratigraphic correlation chart of modeled units. ( , approximately) 


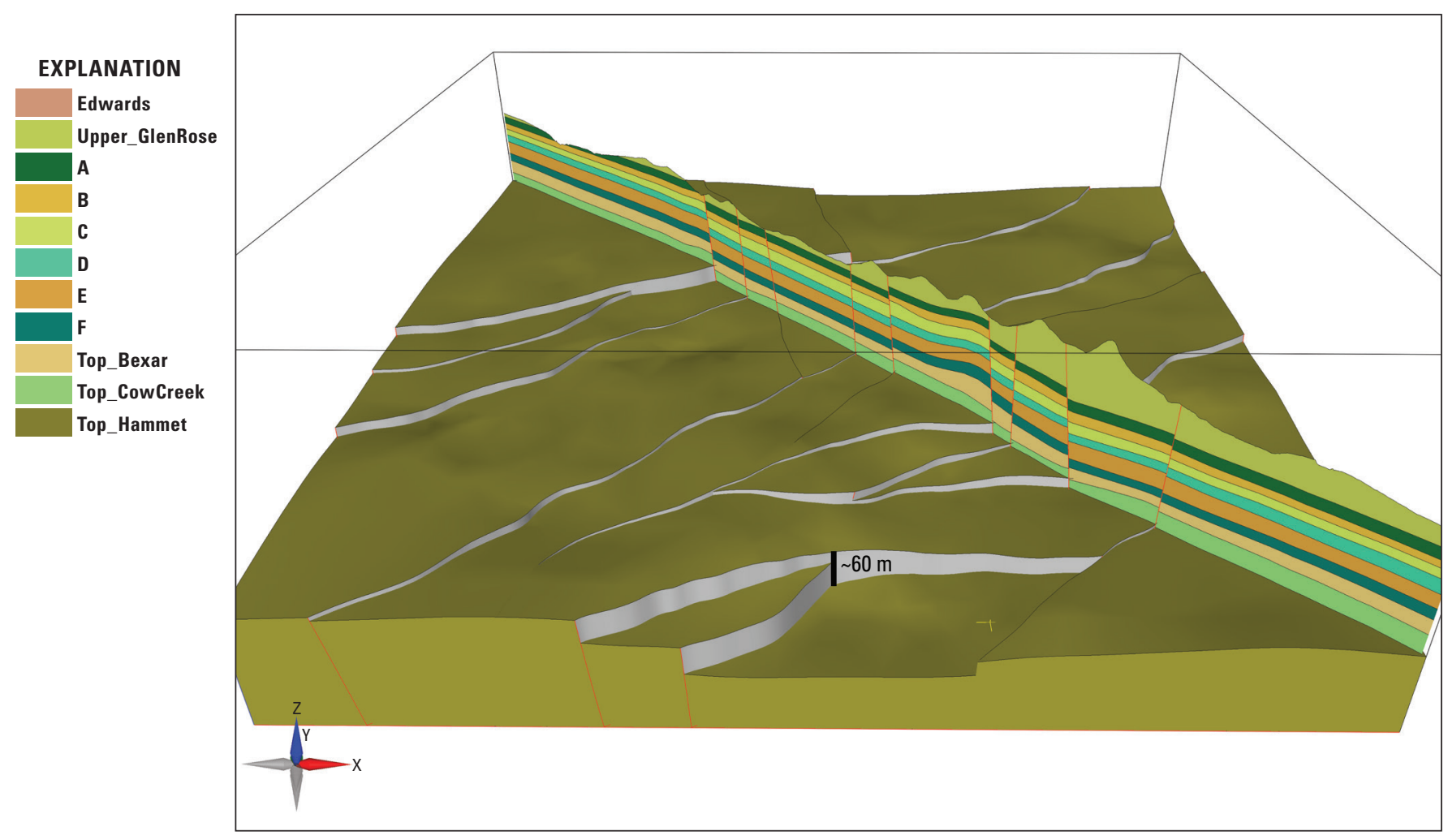

Figure 3. View of faulted top of Hammett hydrostratigraphic unit, cross section showing hydrostratigraphic units, and faults used in the model. View is toward the north. ( , approximately; m, meters)

from MW-5-LGR for the lower member of the Glen Rose Limestone and hydrostratigraphic units A through $\mathrm{F}$ were submitted to Weatherford Laboratories, Inc. (Golden, Colorado), for helium-gas-injection porosity and permeability analyses (Blome and Clark, 2014).

\section{3-D Model Development and Data Management}

The 3-D model was developed using Dynamic Graphics Earth Vision (EV) software. This model integrates spatially referenced contact, fault, and drill-hole data, mapped surface geology, and the digital elevation model (DEM, fig. 4). In addition, other geospatial data in the form of registered images and annotation files were added including: roads, county lines, city limits, the military base boundaries, and earlier mapped geology (figs. 4 and 7). The model was made internally consistent by reviewing the data sets individually and cross-validating against the other data sets to identify errors. Problems with well locations, depth to unit contacts, fault locations, and mapped geology identified during the modeling process were field or data verified, and the model and data sets were updated.

The fault framework was modeled first and includes 14 normal faults (figs. 6 and 7) with steep dips identified during field mapping (Clark, 2004). Modeled faults were added sequentially with faults that traverse the model area first, faults that truncate on other faults second, and faults starting in the model and propagating beyond model extent added last. Some faults had minimal drill-hole information to define vertical displacement; in these cases, surficial geologic maps were used to define the displacement. The minimal fault displacement used to construct the model was 3 meters (m), which also represents the error tolerance of the data sets. Some faults were further constrained because drill-hole data indicated more or less displacement at depth than identified at the surface and/ or the fault trend or dip did not agree with that defined in previous work.

After the fault network was created, hydrostratigraphic surfaces were constructed based on contacts derived from geologic mapping and drill-hole data. Where there was insufficient information, contact data points were extrapolated vertically from previously identified contacts on geologic maps and drill-hole data, that were based on local hydrostratigraphic unit thicknesses. Some of the thickness and surface variations shown in the model may reflect additional faulting and variations in depositional or diagenetic processes that were beyond the objectives of this study.

The top of Hammett Shale Member is the lowermost modeled unit and was used to propagate and validate fault structures shown on geologic maps and to confirm drill-hole data. This was necessary because current geologic modeling 


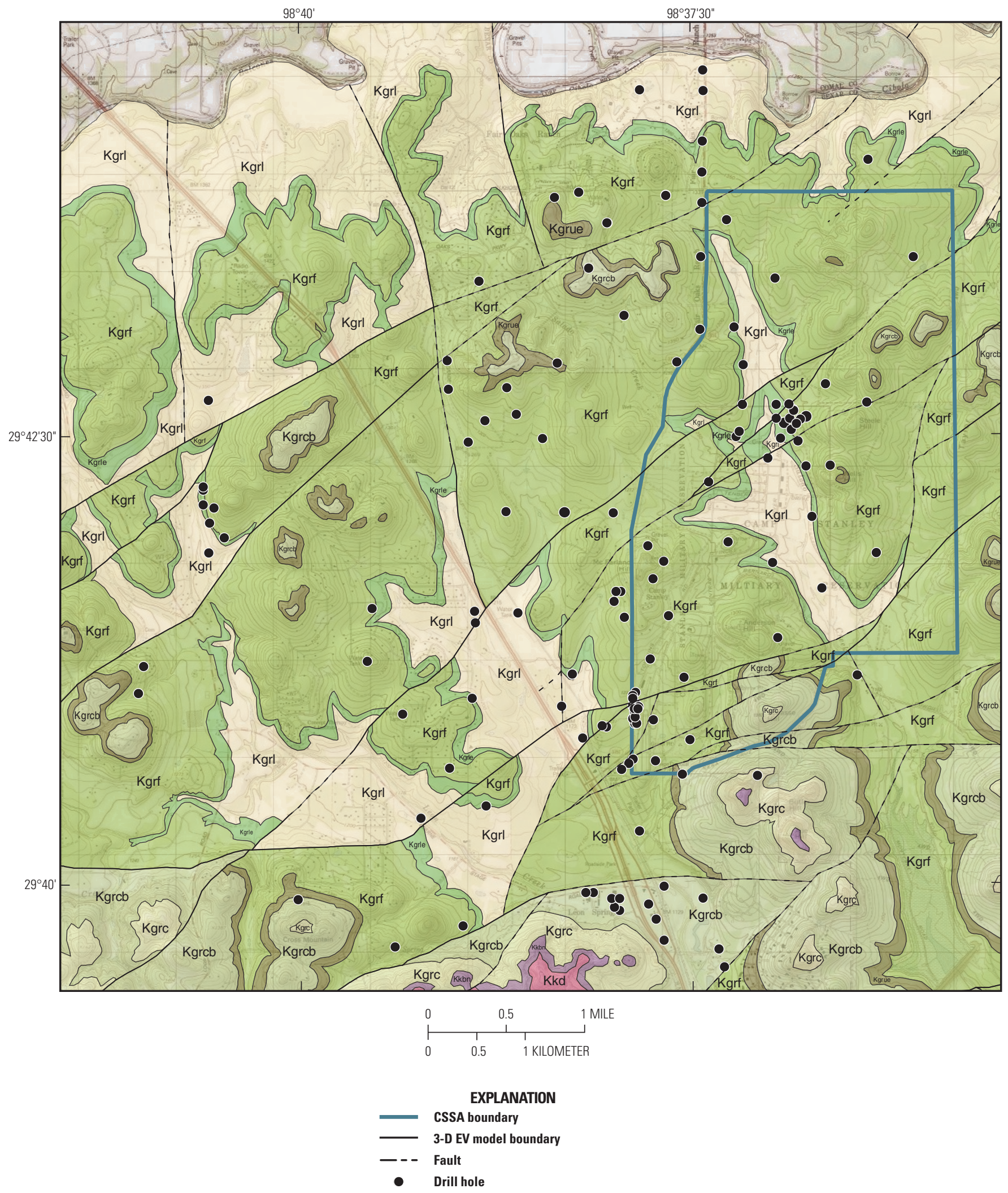

Figure 4. Well locations, previously mapped faults, and mapped surface lithology within the U.S. Army-Camp Stanley Storage Activity (CSSA) model area (from Blome and Clark, 2014). 


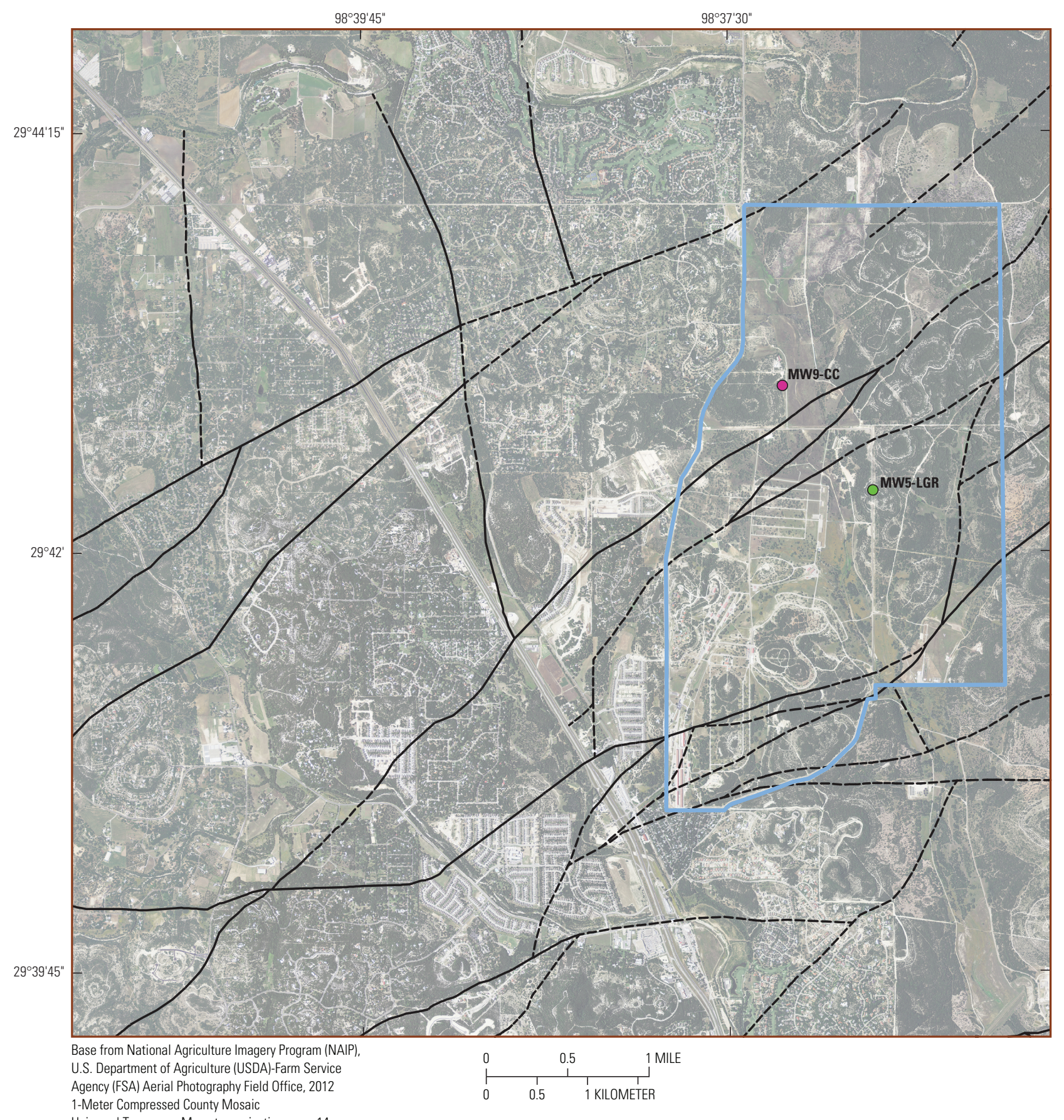

Universal Transverse Mercator projection, zone 14

North American Datum of 1983

\section{EXPLANATION}

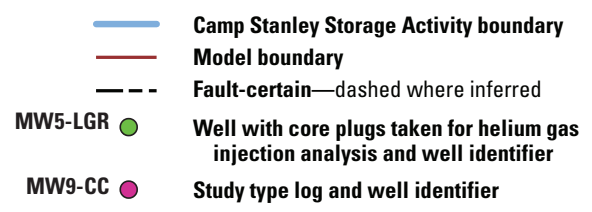

Figure 5. Study area, orthophoto quadrangle image, original structure overlay, core type log drill-hole locations, and the Camp Stanley Storage Activity Area boundary, modified from Clark and others (2009). 

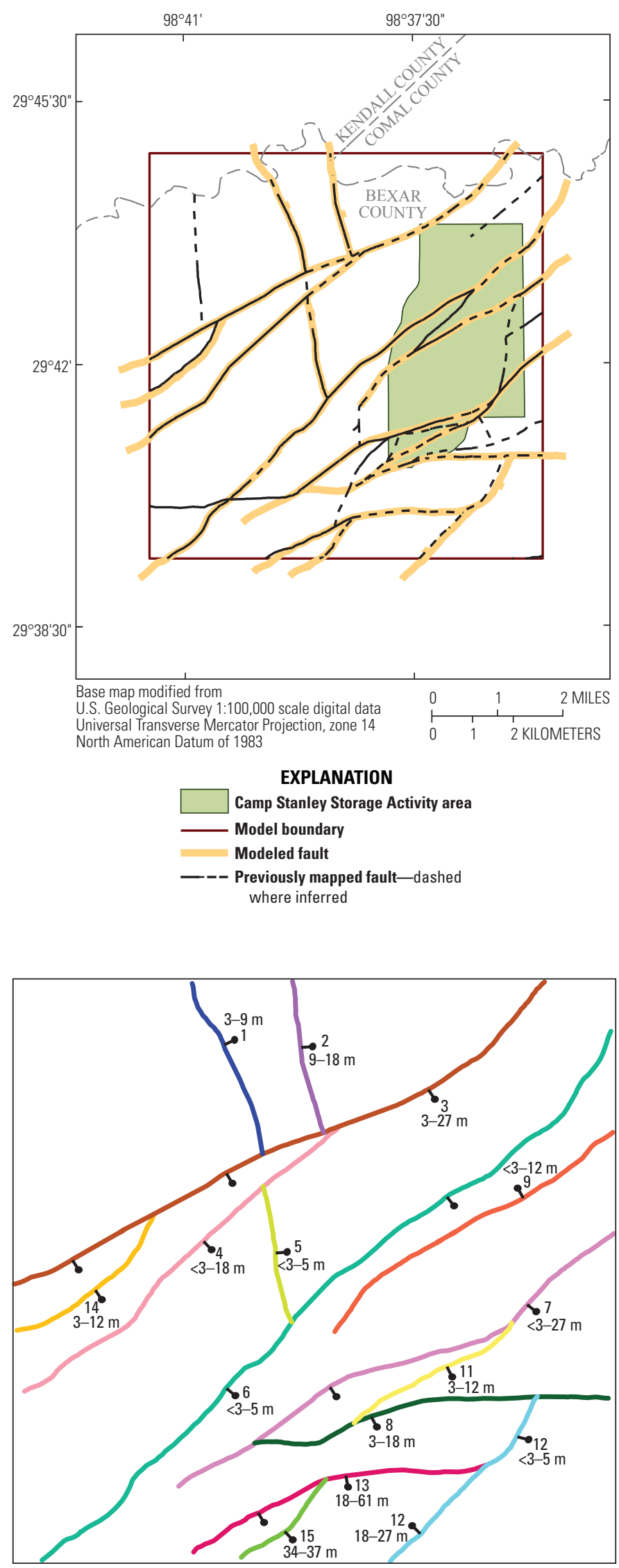

Figure 6. Fourteen faults used in the construction of the threedimensional model as related to the previously mapped faults.

techniques build layers from reference surfaces from the bottom up. This model contains a lower and upper reference surface. Reference surfaces contain fault offsets, folds, and other structural features which are propagated through the other surfaces. Faults and geologic surfaces will continue along calculated trends until some constraint is reached. Constraints are other faults, geologic surfaces, or model boundaries.

The final data layer is the $10-\mathrm{m}$ DEM. The DEM serves two purposes: (1) it caps the model as the final geologic layer, and (2) it sculpts the final data layer and underlying model units defining the topographic relief. The sculpting of the underlying units provides surface contacts observed on geologic maps, and is used as a way to validate geologic interpretations and to provide spatial location information (fig. 8).

\section{Hydrostratigraphy}

The geologic map used for the CSSA model area was derived from the recent mapping efforts in northern Bexar County, Tex., by Clark and others (2009), and includes both the lithostratigraphy and hydrostratigraphy of the lower part of the Edwards aquifer down to the uppermost middle Trinity aquifer (figs. 2 and 8). Maclay and Small (1976) subdivided the Edwards aquifer into eight hydrostratigraphic units. Within the study area, only the lower part of the Edwards aquifer is present that includes the Dolomitic (Kkd) and Basal nodular (Kkbn) hydrostratigraphic units as mapped by Clark and others (2009). As shown on figure 4 and in the model, rock outcrops associated with the Edwards aquifer only cap hilltops south of the CSSA and do not represent recharge areas for the Edwards aquifer within the model.

Clark (2003, 2004) and Clark and others (2009) subdivided the upper Trinity aquifer into five hydrostratigraphic units, in descending order, the cavernous (Kgrc), Camp Bullis (Kgrcb), upper evaporate (Kgrue), fossiliferous (Kgrf), and lower evaporite (Kgrle) units (fig. 2). For modeling purposes, the units of the Edwards aquifer were combined into one model unit referred to as the "Edwards," and the hydrostratigraphic units of the upper Trinity aquifer were combined into one model unit refered to as the "Upper_GlenRose." The hydrostratigraphic units are describe by their lithologic and porosity characteristics in the following sections.

Figure 7. Fourteen modeled faults, fault dip direction and the range of calculated displacements along the fault plane. $(<$, less than; $m$, meters). Fault 10 was removed from the original model because of new data. 


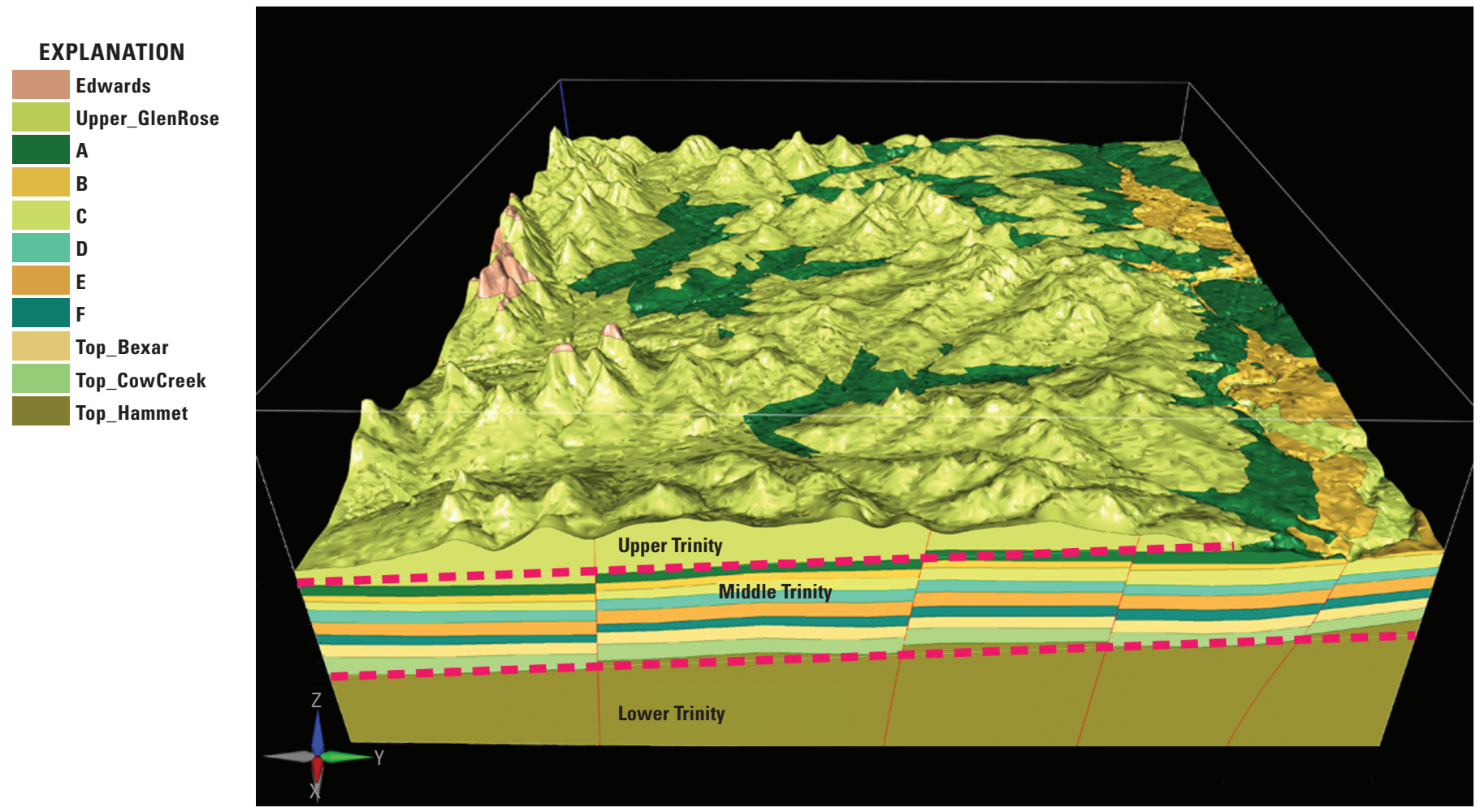

Figure 8. The 3-D model area, surface topology, surface and subsurface hydrostratigraphic units, and structure. Rocks of the Edwards aquifer (in pink) are isolated and cap some of the hills in the southern part of the study area. View is from the east looking west.

\section{Modeled Edwards Aquifer Hydrostratigraphic Units (Edwards)}

Kkd Dolomitic hydrostratigraphic unit: Alternating mudstone, wackestone, and grainstone; local showings of chert, 32-42 m thick. The massively bedded unit weathers light gray in outcrop and contains abundant forms of the rudist Toucasia (Stein and Ozuna, 1995; Small and Clark, 2000). The dolomitic unit is the most cavernous of the Edwards aquifer in the Bexar County area; cave development is directly related to faults and fractures. The unit is hydrologically considered to possess mostly nonfabric-selective porosity (Choquette and Pray, 1970) except where dissolution along bedding planes yields water. This unit is only present along the highest hilltops along the southern edge of the model boundary (fig. 4). Because this unit is "perched" among the hilltops, the outcrops are not recharge features for the Edwards aquifer.

Kkbn Basal nodular hydrostratigraphic unit: Shaley nodular limestone and burrowed-mudstone to wackestone, 6-21 m thick. Identified in the field by nodular gray mudstone containing black rotund bodies, commonly called "brb's," and the occurrence of miliolids, gastropods, and the fossil oyster Protocardia texana (Stein and Ozuna, 1995; Clark, 2003). Minor lateral cavern development at the surface and nonfabric-selective porosity. Considered regionally to be a lower confining unit of the Edwards aquifer. This unit is locally water bearing through dissolution along bedding planes. Within the model boundary, this unit is only present along the highest hilltops south of CSSA (fig. 4). Because this unit is "perched" amongst the hilltops, the outcrops are not recharge features to the Edwards aquifer. The dolomitic and basal nodular are combined and shown in the model.

\section{Modeled Upper Trinity Aquifer Hydrostratigraphic Units (Upper_GlenRose)}

Kgrc Cavernous hydrostratigraphic unit: Interfingering mudstone, clay, and wackestone to grainstone, greater than $35 \mathrm{~m}$ thick. An abundance of fabric selective caves as well as fabric selective fractures and channels. This unit is more permeable relative to the underlying Camp Bullis unit (Clark, 2003) which has few identified caves or channels.

Kgrcb Camp Bullis hydrostratigraphic unit: Interfingering mudstone, clay, and wackestone to grainstone, 35-44 m thick. Named after the Camp Bullis Military Training Reservation that is located northwest of San Antonio, Tex. Local occurrences of Protocardia texana (Conrad) and Tylostoma sp. may be found, less karst development and permeability as compared to the overlying Cavernous unit. The Camp Bullis unit exhibits little porosity and permeability from field observation (Clark, 2003). Porosity where observed is mostly fabric selective interparticle and intercrystalline. The unit's selective fracture porosity has little solution enlargement. The unit is a confining layer except where nonfabric selective caves are present (Clark, 2004). 
Kgrue Upper evaporite hydrostratigraphic unit: Partly to mostly dissolved soluble carbonate rock, 5-7 m thick. Unit is characterized by nonfabric selective breccia with collapse features. Fabric selective molds (boxwork) porosity typically intercepts the downward percolation of groundwater and diverts water laterally (Clark, 2004), discharging at springs and seeps.

Kgrf Fossiliferous hydrostratigraphic unit: Thinly bedded, silty mudstone, wackestone, packstone, clay, and mudstone with boundstone formed from locally massive rudist biostrome, $70-85 \mathrm{~m}$ thick. Unit contains several identifiable marker beds that include boundstone. Fossil assemblages include abundant Orbitulina texana (Roemer), Porocystis golobularis (Giebel), Tapes decepta (Hill), Protocardia texana (Conrad), Loriolia sp., Turritella sp., Hemiaster sp., Neithea sp., and various species of mollusks. Fabric selective, moldic porosity seen occurs in the biostrome where present near the top of the unit. The biostrome also contains nonfabric selective porosity associated with vugs, fractures, and caves. This porosity appears interconnected, thus making the biostrome one of the more permeable zones as seen in field (Clark, 2003). The non-biostrome part of the unit is locally dominated by nonfabric selective porosity in the form of fractures and caves. According to William Pearson (written commun., September 10, 2013) of Parsons Corporation, this unit consists of laterally discontinuous perched water zones that are low-yielding on the order of 10 gallons per minute (gpm) or less, and temporally saturated in response to localized precipitation.

Kgrle Lower evaporite hydrostratigraphic unit: Partially to mostly dissolved sequence of evaporites similar to that in the upper evaporite hydrostratigraphic unit but also includes highly altered crystalline limestone and chalky mudstone $2-5 \mathrm{~m}$ thick. The unit appears as a yellow to white calcareous mud, and, in some places, contains gray sparite. Fossil assemblages include Nerinea romeri, Orbitolina texana, Porocystis globularis, and Turritella $s p$. in addition to numerous species of pelecypods and gastropods, shell fragments and worm burrows. Index fossil Corbula sp. forms the base of the unit. The unit contains moldic (boxwork) and breccia porosity from collapse. This unit diverts groundwater laterally as reflected in the many seeps and springs near the base of the unit (Clark, 2004).

\section{Modeled Middle Trinity Aquifer Hydrostratigraphic Units}

The subsurface units composing the middle Trinity aquifer were determined from geophysical log analyses and core descriptions of the wells MW5-LGR and MW9-CC (Blome and Clark, 2014). The reported porosity values were based on data from Weatherford Laboratories, Inc., helium injection tests (Blome and Clark, 2014). The following subsurface lithostratigraphic and hydrostratigraphic units were used in the model (fig. 8).
Hydrostratigraphic unit A: Mostly shale, with laminae of micritic limestone; lower part of unit is clay-rich with laminae of micritic limestone, $11 \mathrm{~m}$ thick. Locally may contain fossil fragments and vugs, lower part of unit contains rip-up clasts with shell debris that may show moldic porosity and shell debris, fossil assemblage includes: larger oyster fragments, echinoids, Orbitalina sp., and possible Corbula $s p$ near top of unit. Porosity types identified were fabric selective intergranular and moldic, and nonfabric selective vug; values varied from 10.9 to 24.5 percent (Blome and Clark, 2014). Nonfabric selective porosity such as karst, faults, and fractures were also reported by William Pearson (written commun., September 10, 2013) of Parsons Corporation. Like the fossiliferous unit of the upper member of the Glen Rose (Kgrf Fossiliferous hydrostratigraphic unit), this interval consists of laterally discontinuous perched water zones that are low-yielding, on the order of $10 \mathrm{gpm}$ or less, and temporally saturated in response to local precipitation events (William Pearson, written commun., September 10, 2013).

Hydrostratigraphic unit B: Very calcareous biomicrite and gray shale, $12 \mathrm{~m}$ thick. Decreasing clay towards lower part of unit, with localized fossil beds; unit contains light to dark gray burrow structures. Micrite shows styolitic laminae and may contain abundant shell fragments and vugs. Fossil assemblages include: fenestrella-type bryozoans, the bivalve Corbula sp. (?), and whole oyster shells. Porosity types identified were fabric selective intercrystalline and moldic, and nonfabric selective vug; values varied from 14.1 to 27 percent (Blome and Clark, 2014). According to William Pearson (written commun., September 10, 2013) under flood-stage conditions with a high degree of saturation, this unit has shown a capacity to quickly transmit groundwater in zones of high moldic porosity. Pearson (written commun., September 10, 2013) also states that under normal condtions the occurrence of groundwater is perched and generally on the order of 10 gpm or less.

Hydrostratigraphic unit C: Mostly biomicrite with some fossils, $20 \mathrm{~m}$ thick. Shell fragments and some molds appear to be filled with oolites, shale increasing with depth. Porosity types identified were fabric selective moldic and nonfabric selective vug; values varied from 13.9 to 22.9 percent (Blome and Clark, 2014). The fabric selective porosity is considered low, 13.9 percent, because of its fine-grained nature and lack of moldic porosity (William Pearsons, written commun., September 10, 2013). Parsons Corporation (William Pearsons, written commun., September 10, 2013) reported that this unit is not a significant groundwater producer except locally, where significant fracturing has occurred.

Hydrostratigraphic unit D: Biomicritic limestone with shale, $13 \mathrm{~m}$ thick. Shale increasing toward bottom of unit with some rip-up clasts. Fossil assemblages include: shell fragments, burrows, oyster fragments, and whole oyster shells. Porosity types identified were fabric selective moldic and nonfabric selective vug; values varied from 11.0 to 22.2 percent (Blome and Clark, 2014). The localized vugs associated with moldic porosity (fabric selective) may produce 
small amounts of groundwater on the order of $10 \mathrm{gpm}$ or less (William Pearsons, written commun., September 10, 2013). According to William Pearsons (written commun., September 10, 2013), nonfabric selective porosity in the form of fractures has also been observed to yield minimal groundwater. Overall, the water-bearing capacity of this interval varies greatly within short distances.

Hydrostratigraphic unit E: Micritic to biomicritic limestone with local occurrences of shell fragments, $22 \mathrm{~m}$ thick. Shell fragments are abundant in some occurrences. Porosity was fabric selective intergranular and intercrystalline, porosity varied from 12.1 to 19.8 percent. (Blome and Clark, 2014). With the exception of the vuggy biomicrite along its basal boundary, most groundwater movement through this unit is limited to nonfabric selective features such as fractures (William Pearson, written commun., September 10, 2013). This unit was not found to be very permeable (12.1 percent porosity) based upon drilling activities at CSSA by the Parsons Corporation (William Pearson, written commun., September 10, 2013).

Hydrostratigraphic unit F: Micritic limestone with local occurrences of dolomite, coral, and clay, $16 \mathrm{~m}$ thick. Contains approximately one foot thick clay layer in upper part of unit with coral in middle part of unit. The unit contains ooids, shell fragments and gastropods. Porosity was fabric selective moldic and nonfabric selective vugs, both of which were commonly large, values varied from 16 to 30.2 percent (Blome and Clark, 2014). William Pearson (written commun., September 10, 2013) has reported that Unit $\mathrm{F}$ is the main groundwater-producing zone within the lower Glen Rose member of the Middle Trinity aquifer. Compared to other units of the lower Glen Rose member, the abundance of moldic porosity provides an increased capacity for groundwater storage and yield. The occurrence of this moldic porosity has been well documented within drill holes drilled at CSSA and neighboring areas (William Pearson, written commun., September 10, 2013). Extensive packer testing and discrete interval groundwater sampling indicate that the unit is capable of yielding groundwater in excess of 75 (gpm) (William Pearson, written commun., September 10, 2013). In areas of fractures, karst, or small caverns, groundwater production can exceed $150 \mathrm{gpm}$ (William Pearson, written commun., September 10, 2013).

\section{Following are both Hydrostratigraphic and Lithostratigraphic Units}

Bexar Shale Member: Biomicritic limestone with fossil fragments, layers of dolomite, local occurrences of rip-up clasts, and showing soft sediment deformation, $19 \mathrm{~m}$ thick. Fossil fragments include: shell fragments and oyster and oyster fragments. Lower part of unit is biomicritic limestone with petroliferous black shale and fossil debris. Porosity was fabric selective intercrystalline and moldic, and nonfabric selective vugs, with visible porosity decreasing with depth. Porosity values varied from 9.2 to 23.8 percent in the upper $4 \mathrm{~m}$; no samples were obtained as part of this study for lower part of the unit (Blome and Clark, 2014). The Bexar Shale Member forms a relatively impermeable barrier for the overlying water bearing zones (William Pearson, written commun., September 10, 2013). Significant vertical water movement in the Bexar Member is through fractures and faults (William Pearson, written commun., September 10, 2013). According to William Pearson (written commun., September 10, 2013), its capacity for low water production and hydraulic separation between the lower Glen Rose and Cow Creek Limestone Member has been demonstrated at CSSA in wells completed in this unit.

Cow Creek Limestone Member: Micritic limestone and limestone with shale, local friable carbonate-rich sands, lower part of unit is dolomitic, 22-m thick. Unit contains fossil fragments, few styolites, and oyster shells. Lower part is dolomitic and micritic limestone, with local occurrences of shell fragments. Shell fragments are mostly oyster and some pelecypods. Porosity is fabric selective intercrystalline and moldic, and nonfabric selective vugs (Blome and Clark, 2014) and fractures (William Pearson, written commun., September 10, 2013). Porosity values were not obtained as part of this study for the Cow Creek Limestone Member. Wells drilled within the study area derive water from Unit F, and the Cow Creek.

Hammett Shale Member: Shaley mudstone, slightly petroliferous and soft mudstone with fine-micritic laminae, grading downward to micritic limestone with abundant fossil fragments, about $18 \mathrm{~m}$ thick based on data from nearby drill holes, only the upper $7 \mathrm{~m}$ were available for core description (Blome and Clark, 2014). Porosity is fabric selective intercrystalline. Porosity values were not obtained as part of this study for the Hammett Shale Member. The Hammett is in gradational contact with the Cow Creek, and forms the lower confining unit for the Middle Trinity aquifer (Ashworth, 1983).

\section{Structure}

Faults in northern Bexar County are part of the Mioceneage Balcones fault system historically called the Balcones fault zone (Hill and Vaughn, 1898; Arnow, 1963; Maclay and Land, 1988; Clark, 2004). The southwest to northeast trending Balcones fault zone is an extensional system of normal en echelon faults, downthrown to the southeast (George, 1952; Clark, 2004). Locally, high-angle normal faults are common (Clark, 2004). The resulting fault blocks occasionally form horst and graben geologic structures (Maclay and Small, 1976; Small, 1986; Clark and others, 2013). One such graben was identified during construction of the 3-D model in the central part of the study area; the graben trends northeast to the southwest (fig. 9). In the study area, fault dips were interpreted from 52 degrees to near vertical depending on the lithology of the rocks being faulted. The dip information is based on field mapping and drill-hole data (Clark, 2004). 

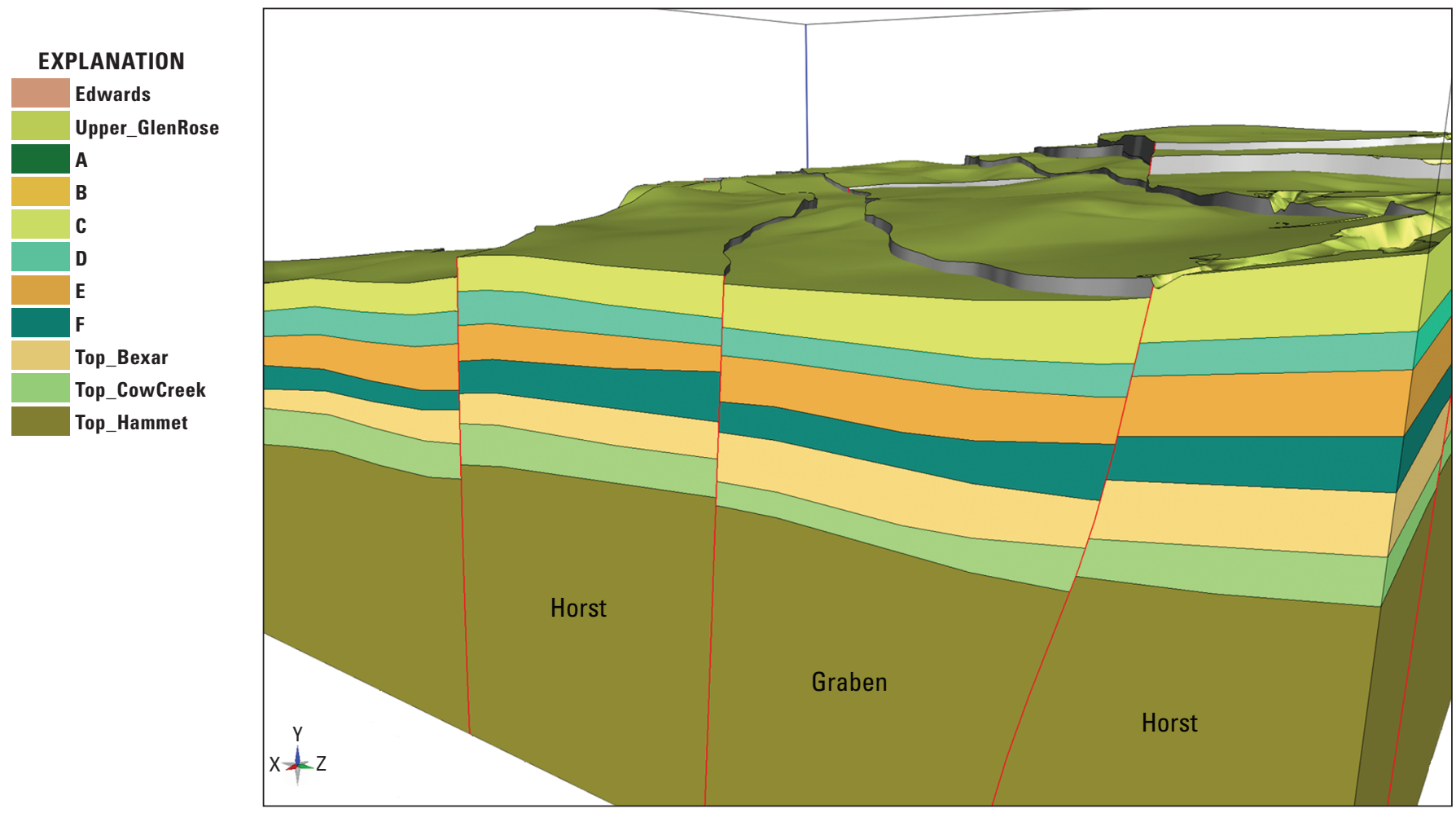

Figure 9. Horst and graben structures in northeast part of model area, view is from northeast looking southwest.

Although most fault displacements identified in the study area are $6 \mathrm{~m}$ or less, a series of closely spaced faults near the southern boundary of the CSSA results in greater displacements (fig. 7). Near the south central part of the study area is a fault with up to $60 \mathrm{~m}$ of displacement (fig. 3). Some faults identified in previous reports (Clark, 2004; Clark and others, 2009) were modified during this study because new drill-hole data were available.

\section{Model Construction}

This 3-D geologic model consists of surfaces that represent lithostratigraphic and hydrostratigraphic units and their relations to fault structures. The top of the model depicts the USGS 10-m DEM topography. The geologic elements were selected for modeling because of their hydrologic significance and their ease of identification from subsurface geophysical analysis of drill-hole data.

EarthVision software was used to create, compile, and display the model because of the ability of the software to interactively use and view different data types. In addition, the software can define and show faulted geologic surfaces while maintaining structural complexity and integrity in three dimensions. The software creates 3 -D mathematically defined surfaces from $\mathrm{X}, \mathrm{Y}$, and $\mathrm{Z}$ data points. For this model, $\mathrm{X}$ and $Y$ coordinates are Universal Transverse Mercator (UTM), Ellipsoid, GRS 1980/NAD 83, zone 14 in meters; and Z values are elevation in feet, North American Datum. Modeled surfaces were derived using the native minimum surfacetension gridding algorithm of the software to more closely model the data and to provide a realistic geologic surface. The gridded lithologic and hydrostratigraphic surfaces are generated in a two-stage process: an initial grid estimate followed by biharmonic iterations. Initial grid nodes are estimated from the data; these are also called scattered data. Data points used for the initial estimate depend on the distribution of the scattered data. Once the estimate is complete, the grid nodes are reevaluated by a number of iterations using a biharmonic cubic-spline function. So that grid nodes still adhere to the scattered data, a scattered data feedback algorithm follows each biharmonic iteration. These modeling steps result in the curvature of the surface being distributed between data points rather than concentrated at data points. This generates a more natural looking modeled surface of the grid nodes that reflect the scattered data. More information is available from Dynamic Graphics, Inc., at http://www.dgi.com.

Volumes of units are defined and shown as the space between (1) two surfaces, (2) surfaces and fault planes, or (3) surfaces and model extents. The software follows basic geologic rules to define depositional, channel-fill, or unconformable contacts and surfaces. Surfaces can be modified by any or all of the following: adding data points to a surface; altering gridding parameters; and using smoothing algorithms in any or all of the $\mathrm{X}, \mathrm{Y}$, and $\mathrm{Z}$ dimensions. Surfaces are modeled using existing data. If necessary, because of faulting or characteristics of the modeling algorithms, some interpreted data points may be added. This allows considerable discretion to define or refine a surface. Details of the algorithms and how 
data points are used by the software are beyond the scope of this report but are available from Dynamic Graphics, Inc., at http://www.dgi.com.

All modeled faults have lengths greater than 4 kilometers and inferred or known offsets of $3 \mathrm{~m}$ or greater (fig. 4). Dips of faults were assigned from surface exposures where possible; otherwise, they were assigned typical values based on data from local surveys within and near the model area, and from drill-hole information. For modeling, defining faults as through-going versus truncated was determined by geometric relations observed at the surface, as well as by geologic interpretations (fig. 3) from drill-hole data. Where faults were spaced very close together, less than $0.5 \mathrm{~km}$, and/or segmented with common dip and strike, a single fault was modeled. Elliptical boundaries for faults were generated to constrain vertical and horizontal extents, in keeping with general rock mechanical models of fault growth (Nichol and others, 1996).

Model construction started with a few faults and geologic surfaces to test interpretations and modeling techniques and to allow input from the authors to refine the modeling process. After each model iteration was accepted, more data were added, interpretations of stratigraphy and structure were refined, and the model increased in complexity. All data and interpretations were validated using 2- and 3-D visual analyses of data sets and field verification as needed. During the modeling process, fault dips or locations were modified to conform to new drill-hole data. Some data points were added to maintain fault displacements through all faulted surfaces or to remove geologic layers that do not exist at the fault boundary or in the fault block. These data points were kept to a minimum. This process of model building results in a better understanding of the geology and structure of the U.S.ArmyCamp Stanley Storage Activity area.

\section{Conclusion}

The 3-D model of the U.S. Army-Camp Stanley Storage Activity area presents an internally consistent interpretation of lithologic and hydrostratigraphic surfaces and associated volumes developed from geologic and geophysical data. Major structures and rock-unit outcrop patterns of this model are mostly consistent with the geologic maps of Clark and others (2009). Differences seen in the model reflect interpretation of fault relations at depth, fault relations to lithologic contacts, data from field reconnaissance, and surface DEM simplification to fit the scale of the model and meet the practical limitations of software and hardware. Noteworthy are the northeasterly trending, southeasterly step-down faults characteristic of the area, which are potential controls for groundwater flow. The atypical horst and graben features in the northeastern and south central parts of the model have not been reported in previous literature and may influence groundwater flow.

\section{Acknowledgments}

The authors would like to thank the following for their help and support on this project: the management and staff of the U.S. Army-Camp Stanley Storage Activity Office and Parsons Engineering-Science, Inc.; Christopher Biel, formerly of Portage Environmental, for getting this project launched; David V. Smith, for overall review; Kenzie Turner, for geologic and technical review; Scott Pearson for geologic review; and Diana Pedraza, for her help with the drafting.

\section{References Cited}

Arnow, Ted, 1963, Ground-water geology of Bexar County, Texas: U.S. Geological Survey Water-Supply Paper 1588, $36 \mathrm{p}$.

Ashworth, J.B., 1983, Ground-water availability of the Lower Cretaceous formations in the Hill Country of south-central Texas: Texas Department of Water Resources Report 273, $173 \mathrm{p}$.

Barker, R.A., and Ardis, A.F., 1996, Hydrogeologic framework of the Edwards-Trinity aquifer system, west-central Texas: U.S. Geological Survey Professional Paper 1421-B, 61 p.

Blome, C.D., and Clark, A.K., 2014, Key subsurface data help to refine Trinity aquifer hydrostratigraphic units, southcentral Texas: U.S. Geological Survey Data Series 768.

Blome, C.D., and Smith, D.V., 2012, Evolution of 3-D geologic framework modeling and its application to groundwater flow studies: U.S. Geological Survey Fact Sheet 2012-3106, 6 p.

Camp Stanley Storage Activity, 2013, Environmental encyclopedia, v. 5, accessed on August 21, 2013 at http://www.stanley. army.mil/Volume5/Hydrogeologic-Report/Section3.htm.

Choquette, P.W., and Pray, L.C., 1970, Geologic nomenclature and classification of porosity in sedimentary carbonates: American Association of Petroleum Geologists Bulletin, v. 54 , no. 2 , p. $207-250$.

Clark, A.K., 2003, Geologic framework and hydrogeologic features of the Glen Rose Limestone, Camp Bullis training site, Bexar County, Texas: U.S. Geological Survey Water-Resources Investigations Report 03-4081, 9 p., 1 plate, scale 1:24,000.

Clark, A.K., 2004, Geologic framework and hydrogeologic characteristics of the Glen Rose Limestone, Camp Stanley Storage Activity, Bexar County, Texas: U.S. Geological Survey Scientific Investigations Map 2831, scale 1:24,000.

Clark, A.R., Blome, C.D., and Faith, J.R, 2009, Map showing the geology and hydrostratigraphy of the Edwards aquifer catchment area, northern Bexar County, south-central Texas: U.S. Geological Survey Open-File Report 2009-1008, 24 p., 1 plate. 
Clark, A.K., Pedraza, D.E., and Morris, R.R., 2013, Geologic Framework, Structure, and Hydrogeologic Characteristics of the Knippa Gap Area in Eastern Uvalde and Western Medina Counties, Texas: U.S. Geological Survey Scientific Investigations Report 2013-5149, 49 p.

Dunham, R.J., 1962, Classification of carbonate rocks according to depositional texture, in Classification of Carbonate Rocks Symposium: American Association of Petroleum Geologists Memoir 1, p. 108-121.

George, P.G., Mace, R.E., and Petrossian, Rima, 2011, Aquifers of Texas: Texas Water Development Board Report 380, $172 \mathrm{p}$.

George, W.O., 1952, Geology and ground-water resources of Comal County, Texas: U.S. Geological Survey WaterSupply Paper 1138, 126 p.

Hill, R.T., and Vaughn, T.W., 1898, Geology of the Edwards Plateau and Rio Grande Plain adjacent to Austin and San Antonio, Texas, with reference to the occurrences of underground waters, in Eighteenth Annual Report of the Director of the U.S. Geological Survey for the year 1896-1897, Part II: U.S. Geological SurveyAnnual report 18-II, p. 193-321.

Maclay, R.W., and Land, L.F., 1988, Simulation of flow in the Edwards aquifer, San Antonio region, Texas, and refinement of storage and flow concepts: U.S. Geological Survey Water-Supply Paper 2336-A, 48 p.
Maclay, R.W., and Small, T.A., 1976, Progress report on geology of the Edwards aquifer, San Antonio area, Texas, and preliminary interpretation of borehole geophysical and laboratory data on carbonate rocks: U.S. Geological Survey Open-File Report 76-627, 65 p.

Nichol, A., Watterson, J., Walsh, J.J., and Childs, C., 1996, The shapes, major axis orientation and displacement patterns of fault surfaces: Journal of Structural Geology, v. 18, p. 235-248.

Small, T.A., 1986, Hydrogeologic sections of the Edwards aquifer and its confining units in the San Antonio area, Texas: U.S. Geological Survey Water-Resources Investigations Report 85-4259, 52 p.

Small, T.A., and Clark, A.K., 2000, Geologic framework and hydrogeologic characteristics of the Edwards Aquifer outcrop, Medina County, Texas: U.S. Geological Survey Water-Resources Investigations Report 2000-4195, 15 p.

Stein, W.G., and Ozuna, G.B., 1995, Geologic framework and hydrogeologic characteristics of the Edwards aquifer recharge zone, Bexar County, Texas: U.S. Geological Survey Water-Resources Investigations Report 95-4030, 8 p., 1 plate, scale 1:75,000.

Publishing support provided by: Denver Publishing Service Center

For more information concerning this publication, contact: Center Director, USGS Geosciences and Environmental Change Science Center

Box 25046, Mail Stop 980

Denver, CO 80225

(303) 236-5344

Or visit the Geosciences and Environmental Change

Science Center Web site at:

http://gec.cr.usgs.gov/

This publication is available online at

http://dx.doi.org/10.3133/sir20145074 



\section{这}

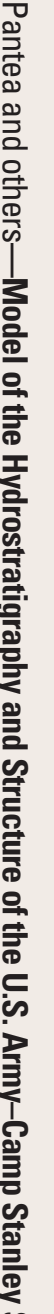

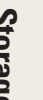

窟:

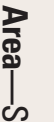

$\frac{2}{\frac{1}{9}}$.

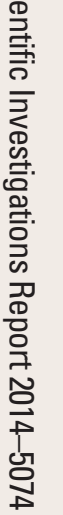

